\title{
Reflections on 'Listening and Empowering: children and science communication' by Matteo Merzagora and Tricia Jenkins
}

\section{Frazer Swift}

Abstract

Keywords
The letter compares and contrasts thinking about making science accessible and relevant to children in science centres and museums with thinking about communication in social history museums.

Public understanding of science and technology; Science centres and museums; Science communication: theory and models

As the head of learning in a social history museum I was fascinated by the introduction to Listening and Empowering [Merzagora and Jenkins, 2013] and the issues it raises about inclusion and science communication. The first thing that occurred me was the lack of equivalent thinking, certainly that I am aware of, about how history is communicated and made relevant to people. But I was also struck by how much of what was discussed could apply equally strongly to history as well as to science. It seemed to me that I, and colleagues who do similar jobs in other history museums, could learn a lot from the interpretive strategies adopted by science museums and centres.

Frank Oppenheimer's comment that 'if people feel they understand the world around them... only then are they able to feel that they can make a difference through their decisions and activities' applies just as much to history as it does to science. Indeed, this fits perfectly with what we at the Museum of London see as the ultimate aim of our learning work - to help create active citizens of the future who wish to make London a better place to live. In terms of inclusivity, as with science communication, we also need to be constantly mindful of the fact that many of our staff think and talk about the history of London, and indeed London today and in the future, from potentially alienating specialist perspectives and can therefore make assumptions unintentionally about our users' levels of interest and understanding.

As with science, I believe that the key to effective engagement with history is not about conveying complex ideas in a digestible way, but about ensuring that the histories we choose to highlight and interpret connect in some way to our audiences' lives today. And of course, the only way to ensure we achieve this is to listen to what they have to say and provide opportunities for meaningful collaboration on the creation of content. 
The issue of whether science communicators might actually be disempowering people by trying to control how they use knowledge, eg by steering people away from challenging accepted scientific facts, was also very interesting. I have certainly seen evidence of this in some teachers, who resist giving their pupils freedom to question history creatively (despite their natural capacity to do so) because of a fear that they will misinterpret it and so arrive at incorrect 'truths'. This was most evident in the Museum of London's 'Ask it, Film it, Share it' project a few years ago which incorporated Philosophy for Children approaches in our digital learning programme and actively encouraged primary school pupils to work together to make decisions about the nature of the workshops in which they were involved.

The introduction also makes the point that children are often treated as mere spectators or recipients in science communication activities, even when these are highly interactive. In my experience there is a great deal of overlap here with activities in history museums, for example in interactive approaches such as drama and role-play, because children are expected to participate in an already decided, historically accepted narrative. It goes on to discuss the idea of the public being involved in the production of knowledge, rather than being receivers of it or debating existing knowledge. I believe that history museums are relatively strong here, eg through their oral history work, co-curation projects and more recently crowdsourcing initiatives. However, as with science communication, there is a tendency for this kind of collaboration to focus on involving adults rather than children, especially when the subjects in question are controversial or contested. At the Museum of London we ran a project last year called Tag London that enabled school children to contribute to our Collections Online database (collections.museumoflondon.org.uk/online/) by categorising objects by type and time period. We are currently working with a number of partners to actively involve young people in designing a programme that will help secondary schools tackle difficult contemporary issues such as homophobia, sexism and racism, and looking at how we can incorporate a greater range of challenging topics into our family events programmes. We are increasingly guided by Arts Council England's Quality Principles for Children and Young People (see artscouncil.org.uk/ what-we-do/cyp/resources/quality-principles/) which, in line with the UN Convention on the Rights of the Child, advocates giving children a voice by actively involving them and developing a sense of belonging and ownership.

Despite the best efforts of learning staff and frequent feedback from visitors to the contrary, history museums also tend to suffer from an ingrained assumption that interactive exhibits and experiences are only for children, not adults. I was surprised that this is also an issue for science museums and centres, given they are generally more hands-on and have been for many years, which reinforced the fact that this is not going to be an easy perception for history museums to overcome.

What I felt was missing from the introduction, which possibly reveals a difference in emphasis between the communication of science and history, is a discussion about other learning outcomes other than the acquisition of knowledge and the deepening of understanding, for example changes in feelings and attitudes, and how these affect behaviour. Certainly much of our work as a social history museum is focused on these kind of outcomes. 
The introduction ends on a positive, forward-looking note, stressing that scientific knowledge can be a tool to 'help him or her design a world as similar as possible to the one we would like to live in.' It seems to me that this is even more the case for history, which is essentially about the human experience - something that I felt could have been more prominent in the discussion. However, in order to realise this potential, history needs to be made relevant to individual learners by making the relationship between the past, present and future more obvious. Science has the advantage of being associated with the future, whereas history is instinctively rooted in the past.

References

Author

\section{How to cite}

This article is licensed under the terms of the Creative Commons Attribution - NonCommercial NoDerivativeWorks 4.0 License.

ISSN 1824 - 2049. Published by SISSA Medialab. http:/ /jcom.sissa.it/.
Swift, F. (2016). 'Reflections on 'Listening and Empowering: children and science communication' by Matteo Merzagora and Tricia Jenkins'. JCOM 15 (04), L01.
Frazer Swift is head of learning at the Museum of London where he leads a team of 25 people over four sites. He has been a tutor at the School of Museum Studies at the University of Leicester for over 10 years, and held several roles at the Science Museum in London, including learning manager, interactive galleries manager and interpretation unit manager. Frazer was originally a secondary school teacher and has worked as a learning consultant for a wider range of museums and galleries throughout the UK. E-mail: fswift@museumoflondon.org.uk.

Merzagora, M. and Jenkins, T. (2013). 'Listening and empowering: children and science communication'. JCOM 12 (3-4), C01. 